\title{
Penerapan Media Puzzle dalam Meningkatkan Hasil Belajar IPS Pada Siswa Kelas III SDN 2 Paseh Kecamatan Paseh Kabupaten Sumedang
}

\section{Application of Puzzle Media in Improving Learning Outcomes of IPS in Students Class III SDN 2 Paseh Kecamatan Paseh Kabupaten Sumedang}

\author{
PUPUNG RAHAYU NOVIATI \\ Program Studi Pendidikan Guru Sekolah Dasar \\ Sekolah Tinggi Keguruan dan IImu Pendidikan Sebelas April Sumedang \\ Jl. Angkrek Situ No.19 Sumedang Jawa Barat 45323 \\ Email: noviati.rahayu@yahoo.com
}

\begin{abstract}
IPS learning outcomes in class III SDN 2 Paseh District Paseh Sumedang District is still relatively low. This is because the learning process still does not actively involve students. To solve the problem, researchers compiled a classroom action research using puzzle media. The formulation of the problem is whether the use of puzzle media can improve student learning outcomes. The purpose of the study is to describe the use of puzzle media in improving student learning outcomes. The benefit of this research is the use of puzzle media improve the learning result of IPS, become teacher reference in improving learning achievement, and become reference for further research. The results of the completion percentage before the use of puzzle media reached $23.1 \%$ of students. Then in cycle III percentage of completeness reaches $80.8 \%$, thus increasing about $57.7 \%$. This shows that the puzzle media is declared effective in improving students' learning ability.
\end{abstract}

Keywords: IPS Learning, Learning Outcomes, Puzzle Media.

\begin{abstract}
Abstrak
Hasil pembelajaran IPS di kelas III SDN 2 Paseh Kecamatan Paseh Kabupaten Sumedang masih tergolong rendah. Hal ini disebabkan proses pembelajaran masih belum melibatkan siswa secara aktif. Untuk mengatasi masalah tersebut, peneliti menyusun penelitian tindakan kelas dengan menggunakan media puzzle. Rumusan permasalahannya adalah apakah penggunaan media puzzle dapat meningkatkan hasil belajar siswa. Tujuan penelitian adalah mendeskripsikan penggunaan media puzzle dalam meningkatkan hasil belajar siswa. Manfaat dari penelitian ini adalah penggunaan media puzzle meningkatkan hasil belajar IPS, menjadi acuan guru dalam meningkatkan prestasi belajar, serta dijadikan referensi bagi penelitian selanjutnya. Hasil persentasi ketuntasan sebelum digunakan media puzzle hanya mencapai $23,1 \%$ siswa. Kemudian pada siklus III persentasi ketuntasan mencapai 80,8\%, sehingga meningkat sekitar 57,7\%. Hal ini menunjukkan bahwa media puzzle dinyatakan efektif dalam meningkatkan kemampuan belajar siswa.
\end{abstract}

Kata Kunci: Pembelajaran IPS, Hasil Belajar, Media Puzzle.

\section{Pendahuluan}

Pendidikan merupakan usaha sadar untuk menyiapkan peserta didik melalui kegiatan bimbingan, pengajaran, dan atau latihan bagi peranannya di masa yang akan datang. Berdasarkan Undang-undang No. 20 Tahun 2003 tentang Sistem Pendidikan Nasional dinyatakan bahwa "Pendidikan adalah usaha sadar dan terencana untuk mewujudkan suasana belajar dan proses pembelajaran agar peserta didik aktif mengembangkan potensi dirinya untuk memiliki kekuatan spiritual keagamaan, pengendalian diri, kepribadian, kecerdasan, akhlak mulia, serta keterampilan yang diperlukan dirinya, masyarakat, bangsa, dan negara".

Pada pendidikan formal siswa akan dikenalkan dengan mata pelajaran IImu Pengetahuan Sosial (IPS). Menurut Rosdijati 
mengatakan bahwa Ilmu Pengetahuan Sosial (IPS) merupakan salah satu mata pelajaran yang diberikan di tingkat SD/MI/SDLB. IPS mengkaji seperangkat peristiwa, konsep, fakta, dan generalisasi yang berkaitan dengan isu sosial. Pada jenjang SD/MI, mata pelajaran IPS memuat materi geografi, sejarah, sosiologi, dan ekonomi. Nursid Sumaatmadja (dalam Supriatna, 2008: 1) mengemukakan bahwa "secara mendasar pengajaran IPS berkenaan dengan kehidupan manusia yang melibatkan segala tingkah laku dan kebutuhannya". IPS berkenaan dengan cara manusia menggunakan usaha memenuhi kebutuhan materinya, memenuhi kebutuhan budayanya, kebutuhan kejiwaannya, pemanfaatan sumber yang ada dipermukaan bumi, mengatur kesejahteraan dan pemerintahannya, dan lain sebagainya yang mengatur serta mempertahankan kehidupan masyarakat manusia.

Sedangkan menurut Leonard (dalam Kasim, 2008:4) mengemukakan bahwa IPS menggambarkan interaksi individu atau kelompok dalam masyarakat baik dalam lingkungan mulai dari yang terkecil misalkan keluarga, tetangga, rukun tetangga atau rukun warga, desa / kelurahan, kecamatan, kabupaten, provinsi, negara, dan dunia. Adapun tujuan pembelajaran IPS yaitu (1) mengenal konsep-konsep yang berkaitan dengan kehidupan masyarakat dan lingkungannya, (2) memiliki kemampuan dasar untuk berpikir logis dan kritis, rasa ingin tahu, inkuiri, memecahkan masalah, dan keterampilan dalam kehidupan sosial, (3) memiliki komitmen dan kesadaran terhadap nilai-nilai sosial dan kemanusiaan, dan (4) memiliki kemampuan untuk berkomunikasi, bekerjasama dan berkompetisi dalam masyarakat yang majemuk, ditingkat lokal, nasional, dan global.

Proses pembelajaran IPS menekankan pada pemberian pengalaman langsung untuk mengembangkan kompetensi siswa agar dapat menjelajahi dan memahami alam sekitar secara ilmiah dan nyata. Materi IPS untuk jenjang Sekolah Dasar tidak dilihat dari aspek disiplin ilmunya karena yang lebih dipentingkan adalah dimensi pedagogik dan psikologi serta karakteristik kemampuan berpikir yang bersifat holistik. Pembelajaran dan hasil belajar IPS dapat digali dari fungsi sikap yang terdapat pada diri manusia. Siswa akan memiliki sikap positif terhadap pembelajaran IPS karena mereka merasakan manfaat dari pembelajaran tersebut. Dengan sikap positif tersebut siswa akan mempelajari
IPS secara optimal sehingga berpengaruh secara signifikan terhadap peningkatan hasil belajar IPS.

Keberhasilan pembelajaran IPS di Sekolah Dasar tidak terlepas dari peran guru sebagai komponen utama dalam pendidikan. Berdasarkan Peraturan Pemerintah RI Nomor 74 Tahun 2008 tentang Guru Bab 1 pasal 1 dinyatakan bahwa "guru adalah pendidik profesional dengan tugas utama mendidik, mengajar, membimbing, mengarahkan, melatih, menilai, dan mengevaluasi siswa pada pendidikan anak usia dini jalur pendidikan formal, pendidikan dasar, dan pendidikan menengah". Peran guru sangat diperlukan bukan hanya sebagai pemberi materi pelajaran sekaligus sebagai pembimbing dan fasilitator dalam kegiatan pembelajaran. Pelaksanaan proses pembelajaran dikatakan baik apabila aktivitas belajar berpusat pada siswa. Sedangkan pembelajaran dikatakan efektif apabila seluruh siswa dapat terlibat secara aktif, baik mental, fisik, maupun sosialnya.

Menurut Sugiyanto (2015: 24), siswa SD mempunyai beberapa karakteristik, yaitu "(1) anak SD senang bermain; (2) anak SD senang bergerak; (3) anak SD senang bekerja dalam kelompok; (4) anak SD senang merasakan atau memperagakan sesuatu secara langsung". Oleh karena itu, perlu adanya suatu bentuk pembaharuan dalam proses pembelajaran agar lebih berpusat pada siswa.

Salah satu upaya untuk menciptakan pembelajaran yang menyenangkan adalah dengan menggunakan permainan edukatif. Seperti diketahui, dunia anak-anak seusia murid SD adalah dunia bermain. Melalui keterlibatannya dalam permainan, mereka dapat mengembangkan dirinya serta mulai memahami status dan perannya dalam kelompok teman sebayanya. Bermain bagi anak adalah alat utama yang menjadi latihan untuk pertumbuhan karena anak langsung mencoba sesuatu secara aktif. Bermain sambil belajar bermanfaat untuk memahami peran dan statusnya dalam masyarakat kelak setelah dewasa.

Tetapi kenyataan di lapangan, dalam proses belajar mengajar masih banyak guru yang hanya terpaku pada buku ajar sebagai satu-satunya sumber belajar. Sehingga pembelajaran hanya terpusat pada penyampaian buku ajar saja. Kurangnya keterampilan guru dalam mengembangkan pendekatan, model, maupun metode mengakibatkan siswa kurang aktif dalam 
proses belajar mengajar. Dengan demikian, pembelajaran hanya berpusat pada guru, sehingga aktivitas dan motivasi belajar siswa menjadi sangat rendah.

Salah satu mata pelajaran yang dianggap masih rendah tingkat pemahaman siswa terhadap materi yang dipelajari yaitu IPS. Hal ini terjadi karena pembelajaran tidak ditunjang dengan penggunaan media dan metode yang tepat. Padahal jika itu mampu diterapkan akan menyebabkan peserta didik fokus atau berkonsentrasi dan tidak merasa bosan ketika pembelajaran berlangsung.

Hasil observasi awal di kelas III SDN 2 Paseh Kecamatan Paseh Kabupaten Sumedang, diketahui bahwa kualitas pembelajaran IPS pada materi jenis-jenis pekerjaan yang menghasilkan barang dan jasa masih tergolong rendah. Pembelajaran IPS yang dilakukan masih belum melibatkan siswa secara aktif, sehingga hasil belajar siswa pun menjadi rendah. Oleh karena itu, perlu pemilihan metode pembelajaran yang dapat meningkatkan hasil belajar siswa. Hasil observasi awal diperoleh data bahwa dari jumlah siswa 26 orang hanya 2 orang yang telah mencapai kriteria ketuntasan minimum (KKM) dengan KKM 70. Dengan demikian ketuntasan belajar IPS baru mencapai 7,7\%.

Untuk mengatasi masalah di atas, peneliti menyusun rencana kegiatan penelitian tindakan kelas (PTK) dalam upaya meningkatkan hasil belajar siswa dalam pembelajaran IPS dengan menggunakan media puzzle. Media puzzle merupakan alat permainan edukatif yang dimainkan dengan cara membongkar pasang kepingan puzzle berdasarkan pasangannya. Menurut Rosdijati (2002: 34), media puzzle mempunyai fungsi sebagai berikut (1) melatih konsentrasi, ketelitian dan kesabaran, (2) melatih koordinasi mata dan tangan, (3) memperkuat daya ingat, (4) mengenalkan anak pada konsep hubungan, (5) dengan memilih gambar/bentuk, dapat melatih anak untuk berpikir matematis (menggunakan otak kiri).

Penggunaan media puzzle dalam meningkatkan hasil belajar IPS siswa telah dilakukan oleh beberapa peneliti sebelumnya, diantaranya oleh Rosiana Khomsoh PGSD FIP, Universitas Negeri Surabaya dengan judul Penggunaan Media Puzzle untuk Meningkatkan Hasil Belajar Siswa dalam Pembelajaran Ilmu Pengetahuan Sosial di Sekolah Dasar. Subjek dan lokasi penelitian yaitu siswa kelas V SDN Candirejo II/173 Loceret-Nganjuk. Adapun alasan peneliti melakukan penelitian tentang media Puzzle ingin membandingkan keefektifan media yang sama pada kelas dan kondisi wilayah yang berbeda. Serta oleh Chairani dengan judul Efektivitas Media Pembelajaran Peta Buta Berbasis Puzzle Multimedia Ditinjau dari Hasil Belajar Siswa Kelas VI SD Negeri Sonosewu Bantul Yogyakarta Tahun Ajaran 2016-2017.

Berdasarkan latar belakang di atas dapat dirumuskan tujuan penelitian ini adalah untuk mendeskripsikan penggunaan media puzzle dalam meningkatkan hasil belajar pembelajaran IPS siswa pada materi jenisjenis pekerjaan yang menghasilkan barang dan jasa di kelas III SDN 2 Paseh Kecamatan Paseh Kabupaten Sumedang. Sedangkan manfaat penelitian yang dilakukan adalah (1) bagi siswa, diharapkan penggunaan media puzzle dapat meningkatkan hasil belajar IPS, karena memudahkan siswa dalam memahami materi yang diajarkan, (2) bagi guru, hasil penelitian ini diharapkan menjadi acuan guru dalam meningkatkan prestasi belajar siswa, khususnya dalam mata pelajaran IPS, (3) bagi sekolah, dari penelitian ini diharapkan sekolah dapat memberikan konstribusi kepada lembaga pendidikan dalam rangka perbaikan kualitas proses dan hasil pembelajaran, dan (4) bagi peneliti lain, hasil penelitian ini diharapkan dapat dijadikan referensi bagi penelitian selanjutnya.

\section{Hasil Belajar}

Menurut Hermawan (2007: 7) "belajar adalah proses perubahan perilaku, di mana perubahan perilaku tersebut dilakukan sadar dan bersifat menetap, perubahan perilaku tersebut meliputi perubahan dalam hal kognitif, afektif, dan psikomotor". Pengertian belajar tersebut senada dengan apa yang diungkapkan oleh Schwartz (dalam Hamzah, 2009:23) juga mengatakan bahwa, "belajar merupakan perubahan tingkah laku yang relatif menetap, yang tidak berhubungan dengan kematangan, efek obat-obatan, atau keadaan fisiologis, melainkan merupakan hasil pengalaman dan seringkali dipengaruhi oleh latihan". Menurut Gagne (Suprijono, 2009:2) "belajar adalah perubahan disposisi atau kemampuan yang dicapai seseorang melalui aktivitas. Perubahan disposisi tersebut bukan diperoleh langsung dari proses pertumbuhan seseorang secara alamiah". Berdasarkan beberapa pendapat di atas dapat disimpulkan bahwa belajar merupakan perubahan tingkah laku secara relatif permanen dan secara potensial terjadi sebagai hasil dari praktik 
penguatan yang dilandasi tujuan tertentu.

Adapun prinsip-prinsip belajar (Hamzah, 2009: 23) untuk menjadikan kegiatan belajar bisa mencapai hasil yang diinginkan, yaitu: 1) adanya perbedaan individual dalam belajar, yaitu bahwa proses belajar yang terjadi pada setiap individu berbeda dengan yang lainbaik secara fisik maupun secara psikis, 2) prinsip perhatian dan motivasi, dalam proses pembelajaran perhatian berperan amat penting sebagai langkah awal yang akan memacu aktivitas-aktivitas berikutnya, 3) prinsip keaktifan, belajar pada hakekatnya merupakan suatu proses aktif yaitu kegiatan merespon terhadap stimulus pembelajaran, 4) prinsip keterlibatan, prinsip ini berhubungan dengan prinsip aktivitas, bahwa setiap individu harus terlibat secara langsung untuk mengalaminya, dan 5) prinsip balikan dan penguatan, prinsip ini berkaitan dengan teori belajar operant condotioning dan B.F Skinner yang menekankan pada penguatan respon untuk memperolah balikan yang sesuai dengan rancangan pembelajaran. Berdasarkan beberapa pendapat tersebut, maka dapat disimpulkan bahwa dalam proses belajar terdapat prinsip-prinsip yang harus diperhatikan, yaitu perbedaan individu dalam belajar, perhatian dan motivasi, keaktifan siswa, keterlibatan langsung dalam aktivitas belajar dan prinsip balikan atau penguatan.

Menurut Sudjana dan Ibrahim (2014: 9) "hasil belajar adalah kemampuan-kemampuan yang dimiliki siswa setelah ia menerima pengalaman belajarnya". Sedangkan menurut Hamalik (2007: 30) mengemukakan bahwa hasil belajar adalah sebagai terjadinya perubahan tingkah laku pada diri seseorang yang dapat diamati dan diukur bentuk pengetahuan, sikap dan keterampilan. Perubahan tersebut dapat diartikan sebagai terjadinya peningkatan yang lebih baik dari sebelumnya dan yang tidak tahu menjadi tahu. Hasil belajar dapat diartikan sebagai hasil maksimum yang telah dicapai oleh siswa setelah mengalami proses belajar mengajar dalam mempelajari materi pelajaran tertentu. Hasil belajar tidak mutlak berupa nilai saja, akan tetapi dapat berupa perubahan atau peningkatan sikap, kebiasaan, pengetahuan, keuletan, ketabahan, penalaran, kedisiplinan, keterampilan, dan lain sebagainya yang menuju pada perubahan positif.

Indikator hasil belajar menurut Bloom (dalam Arikunto, 2012:130) dalam Taxonomy of Education Objectives membagi tujuan pendidikan menjadi tiga ranah yaitu ranah kognitif, afektif, dan psikomotor. Pengembangan dari masing-masing ranah adalah sebagai berikut : (1) Ranah Kognitif yaitu: (a) Pengetahuan (knowledge) yaitu mengidentifikasi, mendefinisi, mendaftar, mencocokkan, menetapkan, menyebutkan, melabel, menggambarkan, memilih., (b) Pemahaman (comprehesion) yaitu menerjemahkan, merubah, menyamarkan, menguraikan dengan kata-kata sendiri, menulis kembali, merangkum, membedakan, menduga, mengambil simpulan, menjelaskan, c) Penerapan (application) yaitu menggunakan, mengoperasikan, menciptakan/membuat, perubahan, menyelesaikan, memperhitungkan, menyiapkan, menentukan, d) Analisis (analysis) yaitu membedakan, memilih, memisahkan, membagi, mengidentifikasi, merinci, menganalisis, membandingkan, e) Menciptakan/membangun (synthesis) yaitu membuat pola, merencanakan, menyusun, mengubah, mengatur, menyimpulkan, menyusun, membangun, merencanakan., f) Evaluasi (evaluation) yaitu menilai, membandingkan, membenarkan, mengkritik, menjelaskan, menafsirkan, merangkum, mengevaluasi. (2) Ranah Afektif yaitu : (a) Penerimaan (receiving) yaitu mengikuti, memilih, mempercayai, memutuskan, bertanya, memegang, memberi, menemukan, (b) Menjawab/menanggapi (responding) yaitu membaca, mencocokkan, membantu, menjawab, mempraktikkan, memberi, melaporkan, menyambut, menceritakan, melakukan, (c) Penilaian (valuing) yaitu memprakarsai, meminta, mengundang, membagikan, bergabung, mengikuti, mengemukakan, membaca, belajar, bekerja, menerima, melakukan, mendebat, (d) Organisasi (organization) yaitu mempertahankan, mengubah, menggabungkan, mempersatukan, mendengarkan, mempengaruhi, mengikuti, memodifikasi, menghubungkan, menyatukan, (e) Menentukan ciri-ciri nilai (characterization by a value or value complex) yaitu mengikuti, menghubungkan, memutuskan, menyajikan, menggunakan, menguji, menanyai, menegaskan, mengemukakan, memecahkan, mempengaruhi, menunjukkan. (3) Ranah Psikomotor yaitu (a) Gerakan pokok (fundamental movement) yaitu membawa, mendengar, memberi reaksi, memindahkan, mengerti, berjalan, memanjat, melompat, memegang, berdiri, berlari, (b) Gerakan umum (generic movement) yaitu melatih, membangung, membongkar, merubah, melompat, merapikan, memainkan, 
mengikuti, menggunakan, menggerakkan, (c) Gerakan ordinat (ordinative movement) yaitu bermain, menghubungkan, mengaitkan, menerima, menguraikan, mempertimbangkan, membungkus, menggerakkan, berenang, memperbaiki, menulis, (d) Gerakan kreatif (creative movement) yaitu menciptakan, menemukan, membangun, menggunakan, memainkan, menunjukkan, melakukan, membuat, menyusun.

Menurut Sudjana dan Ibrahim (2014: 39), hasil belajar yang dicapai siswa dipengaruhi oleh dua faktor, yaitu faktor dari dalam diri siswa (intern) dan faktor dari luar diri siswa (ekstern). Faktor-faktor tersebut yaitu sebagai berikut, pertama faktor internal 1) kemampuan yang dimiliki siswa, 2) motivasi belajar, 3) minat dan perhatian, 4) sikap dan kebisaan belajar, 5) konsep diri, 6) ketekunan, 7) sosial ekonomi, dan 8) fisik dan psikis. Sedangkan faktor eksternal yaitu lingkungan dan kualitas pengajaran.

\section{Media Puzzle}

Menurut Aqib (2015: 50), "Media pembelajaran adalah segala sesuatu yang dapat digunakan untuk menyalurkan pesan dan merangsang terjadinya proses belajar pada si pembelajar". Sedangkan menurut Sudjana dan Rivai (2015: 196) "media pembelajaran adalah alat atau wahana yang digunakan pendidikan dalam proses pembelajaran untuk membantu menyampaikan pesan pembelajaran". Makna media pembelajaran itu sendiri lebih luas dari:alat peraga, alat bantu mengajar, media audio visual. Dalam pembelajaran terdapat media belajar dan sumber belajar.

Manfaat media dalam penyelenggaraan belajar dan pembelajaran menurut Ginting (2008: 141) yaitu: 1) penyampaian materi pembelajaran dapat diseragamkan, 2) proses intruksional lebih menarik, 3) proses belajar lebih interaktif, 4) jumlah waktu belajar-mengajar dapat dikurangi, 5) kualitas belajar dapat ditingkatkan, 6) proses belajar dapat terjadi kapan dan di mana saja, 7) meningkatkan sikap positif siswa terhadap proses dan bahan belajar, dan 8) peran mengajar dapat berubah ke arah positif dan produktif. Sedangkan menurut Sudjana \& Rivai (2015: 2) manfaat media pembelajaran dalam proses belajar antara lain : 1) pengajaran akan lebih menarik perhatian siswa, sehingga dapa menumbuhkan motivasi belajar, 2) bahan pengajaran akan lebih jelas maknanya sehingga dapat lebih dipahami oleh siswa, dan memungkinkan siswa menguasai tujuan pembelajaran dengn baik, 3) metode mengajar akan lebih bervariasi, tidak sematamata komunikasi verbal melalui penuturan kata-kata oleh guru, sehingga siswa tidak bosan dan guru tidak kehabisan tenaga, apalagi bila guru mengajar untuk setiap jam pelajaran, dan 4) siswa lebih banyak melakukan kegiatan belajar, sebab tidak hanya mendengarkan uraian guru, tetapi juga aktivitas lain seperti mengamati, melakukan, mendemonstrasikan, dan lain-lain.

Menurut Rosdijati (2012: 34) kata "puzzle" berasal dari bahasa Inggris yang berarti "teka-teki" atau bongkar pasang", dengan kata lain media puzzle merupakan media sederhana yang dimainkan dengan bongkar pasang. Adapun macam-macam puzzle diantaranya sebagai berikut, 1) puzzle rakitan (construction puzzle), 2) puzzle batang, 3) puzzle lantai terbuat dari bahan sponge (karet/busa), dan 4) puzzle numerik/ puzzle piramida. Sebagaimana mainan balok, media puzzle juga merupakan mainan edukasi tertua. Puzzle memiliki jenis yang tidak kalah banyak dari jenis mainan lainnya. Bahannya pun beraneka macam, karton, kayu, logam, kain, ataupun sponge. Puzzle dapat berupa jigsaw atau bentuk tiga dimensi, menganut asas potongan homogen atau acak, bisa kepingan besar atau kecil atau gabugan keduanya, dapat berupa gambar yang dipecah atau komponen yang harus digabungkan, serta dapat pula berupa yang disusun pada landasan/bingkai tertentu atau harus dirakit menjadi bentuk tertentu.

Menurut Rosdijati (2012: 34), manfaat media puzzle adalah sebagai berikut 1 ) melatih konsentrasi, ketelitian dan kesabaran, 2) melatih koordinasi mata dan tangan, anak belajar mencocokan keping-keping puzzle dan menyusunnya menjadi satu gambar, 3 ) memperkuat daya ingat, 4) mengenalkan anak pada konsep hubungan, dan 5) dengan memilih gambar atau bentuk, dapat melatih anak untuk berpikir matematis (menggunakan otak kiri).

\section{Hakikat Pendidikan IPS di SD}

Istilah Ilmu Pengetahuan Sosial (IPS) yang secara resmi mulai dipergunakan di Indonesia sejak tahun 1975, dalam istilah Indonesia untuk pengertian "Social Studies" , seperti di Amerika Serikat. Banyak definisi tentang IPS yang telah dirumuskan oleh 
para ahli. Menurut Ischak (2007: 36) " Ilmu Pengetahuan Sosial (IPS) adlah bidang studi yang mempelajari, menelaah, menganalisis gejala dan maslah sosial di masyarakat dengan meninjau dari berbagai aspek kehidupan atau satu perpaduan. Dengan kemajuan teknologi pula sekarang ini orang dapat berkomunikasi dengan cepat di manapun mereka berada melalui handphone dan internet. Kemajuan IPTEK menyebabkan cepatnya komunikasi antara orang yang satu dengan lainnya, antara negara satu dengan negara lainnya. Dengan demikian arus informasi akan semakin cepat pula mengalirnya. Oleh karena itu, diyakini bahwa orang yang menguasai informasi itulah yang menguasai dunia.

Hakikat IPS yaitu suatu tempat atau ruang dipermukaan bumi, secara alamiah dicirikan oleh kondisi alamnya yang meliputi iklim atau cuaca, sumber daya air, ketinggian dari permukaan laut, dan sifat-sifat alamiah lainnya. Jadi bentuk muka bumi seperti daerah pantai, dataran rendah, dataran tinggi, dan daerah pegunungan akan mempengaruhi pola kehidupan penduduk yang menempatinya. Mata pelajaran IPS di Sekolah Dasar merupakan program pengajaran yang bertujuan untuk mengembangkan potensi peserta didik agar peka terhadap masalah sosial yang terjadi di masyarakat, memiliki sikap mental positif terhadap perbaikan segala ketimpangan yang terjadi, yang terampil mengatasi setiap masalah yang terjadi, dan terampil mengatasi setiap masalah yang terjadi sehari-hari baik yang menimpa dirinya sendiri maupun yang menimpa masyarakat. Tujuan tersebut dapat dicapai manakala program-program pelajaran IPS di sekolah diorganisasikan secara baik.

Berdasarkan uraian di atas dapat disimpulkan bahwa IPS adalah mata pelajaran yang berupaya untuk mengembangkan pemahaman siswa tentang bagaimana manusia menjadi individu dan kelompok hidup bersama dan berinteraksi dengan lingkungannya, baik fisik dan sosial. Dengan kata lain, IPS adalah bidang studi yang mempelajari, menelaah, menganalisis gejala dan masalah sosial di masyarakat dengan meninjau dari berbagai aspek kehidupan.

Setiap mata pelajaran pasti mempunyai tujuan. Demikian juga dengan mata pelajaran IPS. Demikian juga dengan mata pelajaran IPS. Berikut adalah tujuan pembelajaran IPS di SD menurut Ischak (2007: 38) yaitu 1) membekali anak didik dengan pengetahuan sosial yang berguna dalam kehidupannya kelak di masyarakat, 2) membekali anak didik dengan kemampuan mengidentifikasi, menganalisis, dan menyusun alternatif pemecahan masalah sosial yang terjadi dalam kehidupan di masyarakat, 3) membekali anak didik dengan kemampuan berkomunikasi dengan sesama warga masyarakat dan berbagai bidang keilmuan serta bidang keahlian, 4) membekali anak didik dengan kesabaran, sikap mental yang positif dan keterampilan terhadap pemanfaatan limgkungan hidup yang menjadi bagian dari kehidupan tersebut, 5) membekali anak didik dengan kemampuan mengembangkan pengetahuan dan keilmuan IPS sesuai dengan perkembangan kehidupan, masyarakat, ilmu pengetahuan dan teknologi.

Melalui pembekalan peserta didik dengan lima tujuan pembelajaran IPS itu, diharapkan mereka dapat hidup di masyarakat dengan baik, dan dapat memecahkan masalah-masalah pribadi maupun masalahmaslaah sosial. Untuk bisa mencapai ke arah itu, "pengembangan pembelajaran IPS di sekolah, harus didasarkan pada landasan pendidikan IPS (PIPS), yang meliputi landasan filosofis, ideologis, sosiologis, antropologis, kemanusiaan, politis, psikologis, dan religius". (Sapriya, 2007:26). Dengan demikian guru harus lebih terampil dalam mengelola pembelajaran agar tujuan pembelajaran IPS tersebut dapat tersampaikan kepada siswa. Dalam rangka pengembangan pembelajaran IPS dengan berpedoman pada landasan-landasan itu, seseorang hendaknya memiliki pemahaman yang baik tentang disiplin ilmu-ilmu sosial yang meliputi struktur, ide, fundamental, pertanyaan pokok (mode of inquiry), model yang digunakan dan konsep-konsep setiap disiplin ilmu. Disamping pemahamannya tentang prinsip-prinsip kependidikan dan psikologis serta permasalahan sosial. Dengan kata lain, setiap orang, terutama guru IPS, dituntut memiliki kemampuan tidak saja perlu menguasai keterampilan baru atau kiat untuk mendidik dan mengajar, tetapi juga memiliki wawasan vertikal yaitu wawasan yang mendalam dan reflektif tentang bidang studi yang diajarkannya, dan wawasan horizontal yaitu wawasan yang melebar yakni ramah terhadap konsep-konsep, proposisi-proposisi dan teori-teori ilmu sosial ataupun ilmu-ilmu budaya, bahkan juga ekologi.

Tuntutan ini menjadi sangat logis mengingat masih ditemukannya kenyataan di kelas, seperti semakin kuatnya gejala erosi sikap dan perilaku berdemokrasi 
di kalangan siswa, seperti sikap yang mau menang sendiri, suka memaksakan kehendak, kurang mengakui pilihan lain, sikap toleran yang semakin melemah, kurangnya empati dan lain-lainnya. Sementara itu, pembelajaran demokrasi melalui pendidikan IPS kurang memberikan konstribusi terhadap pengembangan sikap dan perilaku demokratis. Oleh karena itu, guru harus mempunyai strategi penyampaian pengajaran IPS, yang sebagian besar adalah didasarkan pada suatu tradisi, yaitu materi disusun dalam urutan anak, keluarga, masyarakat/ tetangga, kota, region, negara, dan dunia. Dari uraian di atas dapat disimpulkan bahwa membekali anak didik berdasarkan tujuan pembelajaran IPS di atas akan meningkatkan keterampilan sosial dan intelektual dalam membina perhatian serta kepeduliannya sebagai individu yang bertanggung jawab. Dengan kata lain, pembelajaran IPS memiliki tujuan agar siswa dapat hidup di tengahtengah masyarakat dengan baik dan dapat memecahkan masalah-masalah pribadi maupun masalah-masalah sosial.

Ada beberapa karakteristik pembelajaran IPS yang dikaji bersama ciri dan sifat pembelajaran IPS. Menurut Sapriya (2007: 19) karakteristik pembelajaran IPS adalah sebagai berikut, 1) IPS berussaha mempertautkan teoari ilmu dengan fakta atau sebaliknya, 2) penelaahan dan pembahasan IPS tidak hanya dari satu bidang disiplin ilmu saja, melainkan bersifat komprehensif dari berbagai ilmu sosial dan lainnya sehingga berbagai konsep ilmu secara terintegrasi terpadu digunakan untuk menelaah satu masalah atau topik, 3) mengutamakan peran aktif siswa melalui proses belajar inquiri agar siswa mampu mengembangkan berpikir kritis, rasional dan analitis, 4) program pembelajaran disusun dengan meningkatkan atau menghubungkan bahanbahan dari berbagai disiplin ilmu dan lainnya dengan kehidupan nyata di masyarakat, pengalaman, permasalahan, kebutuhan dan memproyeksikannya kepada kehidupan di masa yang akan datang baik dari lingkungan fisik maupun budayanya, 5) IPS dihadapkan pada konsep dan kehidupan sosial yang sangat labil sehingga titik berat pembelajaran adalah proses internalisasi secara mantap dan aktif pada diri siswa agar memiliki kebiasaan dan kemahiran untuk menelaah permasalahan kehidupan nyata pada masyarakat, 6) IPS mengutamakan hal-hal arti dan penghayatan hubungan antar manusia yang bersifat manusiawi, 7) pembelajaran IPS tidak hanya mengutamakan pengetahuan semata juga nilai dan keterampilannya, 8) pembelajaran IPS berusaha untuk memuaskan setiap siswa yang berbeda melalui program dalam arti memperhatikan minat siswa dan masalahmasalah kemasyarakatan yang dekat dengan kehidupannya, 9) dalam pengembangan program pembelajaran IPS, senantiasa melaksanakan prinsip-prinsip, karakter atau sifat dasar dan pendekatan-pendekatan yang terjadi sebagai ciri IPS itu sendiri.

\section{Metodologi Penelitian}

Metode yang digunakan dalam penelitian ini adalah penelitian tindakan kelas (Classroom Action Research). Penelitian tindakan kelas berbentuk siklus yang mengacu pada rancangan penelitian yang dilakukan oleh Kemmis dan Mc. Taggart yaitu model spiral (Arikunto, 2012:2). Dalam perencanaan Kemmis dan Mc. Taggart menggunakan sistem spiral dengan tahapan-tahapan dimulai dari perencanaan (planning), pelaksanaan tindakan (action), observasi (observation), dan refleksi (reflection), perencaan kembali dan begitu seterusnya. Model ini dilakukan secara berulang sampai perencanaan yang telah dirancang telah mencapai target yang diinginkan. Sebelum pada tindakan, terlebih dahulu melakukan rencana tindakan dengan menggunakan tahapan-tahapan yang telah ditentukan.

Penelitian dilaksanakan di kelas III SDN 2 Paseh Kecamatan Paseh Kabupaten Sumedang. Waktu penelitian dilaksanakan dari bulan Januari sampai maret 2017. Dimulai dari penyusunan penelitian sampai dengan pelaksanaan penelitian. Penelitian ini dilaksanakan pada semeter 2 tahun pelajaran 2016/20017. Subjek penelitian ini adalah siswa kelas III yang berjumlah 26 orang siswa, yang terdiri dari 18 siswa perempuan dan 8 orang siswa laki-laki.Teknik pengumpulan data berupa observasi, tes hasil belajar dan dokumentasi.

\section{Pembahasan}

\section{Keadaan Awal Hasil Belajar Siswa}

Sebelum pelaksanaan penelitian dengan menggunakan media Puzzle, hasil belajar IPS kelas III SDN Paseh yang memenuhi KKM adalah sebanyak 6 siswa atau sekitar $23,1 \%$. Kondisi tersebut menjadikan indikator pada penelitian ini bahwa kemampuan belajar IPS siswa kelas III SDN Paseh adalah 
rendah. Rendahnya kemampuan siswa tersebut di atas disebabkan karena siswa mengalami kesulitan dalam mempelajari IPS. Berdasarkan hasil observasi pada waktu guru mengajar, menunjukkan bahwa pembelajaran yang terjadi cenderung bersifat monoton, satu arah, kurang komunikatif, cenderung bersifat ceramah, serta siswa kurang terlibat aktif.

Berdasarkan kajian awal tersebut, maka perlu suatu pendekatan pembelajaran yang mampu meningkatkan situasi kelas yang kondusif, siswa terlibat aktif dalam belajar, terjadinya komunikasi dua arah, serta siswa meningkat motivasinya untuk belajar. Pembelajaran yang dimaksud adalah pembelajaran dengan menggunakan media Puzzle yang dilaksanakan dalam tiga siklus.

\section{Paparan Siklus I}

Perencanaannya terdiri dari, (1) Guru mempersiapkan materi yang akan diajarkan; (2) Guru mempersiapkan alat peraga berupa Puzzle jenis-jenis pekerjaan yang menghasilkan barang dan jasa; (3) Guru menugaskan kepada siswa untuk membawa buku IPS; (4) Guru mempersiapkan lembar kerja untuk siswa; (5) Guru membagi siswa menjadi kelompok yang terdiri dari 4 anak.

Adapun pelaksanaannya, yaitu: (1) Sebelum di mulai pelajaran siswa di ajak menyanyi, untuk menumbuhkan minat belajar; (2) Siswa menyebutkan jenis-jenis pekerjaan yang berada sekitar lingkungannya; (3) Siswa bersama guru membedakan jenisjenis pekerjaan yang menghasilan barang dan jasa; (4) Siswa secara berkelompok memasangkan kepingan-kepingan Puzzle jenis-jenis pekerjan menjadi bentuk yang utuh.

Pengamatan yang dilakukan adalah pengamatan terhadap siswa dilakukan sebagai berikut 1) Pengamatan terhadap kerja sama siswa dalam kelompok., 2) Pengerjaan soal-soal siklus I. Perilaku siswa terhadap pengerjaan soal-soal siklus I ada yang serius, ada yang masih acuh tak acuh, ada yang tampak bingung dan belum jelas, 3 ) Nilai hasil tes siklus I. Berdasar data hasil tes siklus I dapat diketahui siswa yang mencapai KKM sejumlah 9 orang atau sekitar 34,6\%.

Dampak perlakuan siklus I yang diawali dengan perencanaan, tindakan dan pengamatan berpengaruh pada diri siswa. Pengaruh tersebut dapat dilihat pada hasil nilai tes yang dilakukan. Hasil belajar siswa mengalami kenaikan sekitar $11,5 \%$ dibandingkan data awal.

\section{d. Refleksi siklus I}

Berdasar hasil pengamatan menunjukkan adanya peningkatan hasil belajar siswa meskipun ada siswa yang kurang dalam kerjasama dalam kelompoknya. Beberapa siswa masih sibuk bermain sendiri, bentuk pembelajaran yang diawali dengan menyanyi secara bersama-sama menumbuhkan minat belajar yang lebih baik, namun kekurangannya adalah bila siswa tersebut kurang suka bernyayi.

\section{Paparan Siklus II}

a. Perencanaan

1) Guru mempersiapkan materi yang akan diajarakan.

2) Guru mengatur kelas supaya siswa dapat mengikuti pelajaran dengan baik.

3) Guru mempersiapkan beberapa media Puzzle.

b. Pelaksanaan

1) Siswa mengelompok berdasar kelompok masing-masing.

2) Siswa diajak bernyanyi dan bermain untuk menumbuhkan minat belajar.

3) Siswa menyebutkan aktivitas fisik dan istirahat yang mereka ketahui di sekitarmya..

4) Siswa secara mandiri didalam kelompok memasangkan kepingan-kepingan Puzzle menjadi bentuk utuh.

5) Siswa diberi tugas menceritakan gambar yang ada dalam Puzzle secara bergilir.

6) Siswa diberi sanksi bila tidak bisa menjawab pertanyaan dari guru.

c. Pengamatan

1) Pengamatan terhadap kerja sama siswa dalam kelompok. Pengamatan dilakukan dengan melihat partisipasi siswa dalam kelompok. Pada siklus kedua ini terlihat siswa mulai aktif menceritakan gambar secara bergiliran, 2) Pengerjaan soalsoal Siklus II Siswa mengerjakan soal dengan antusias, hal tersebut dikarenakan minat belajar semakin tinggi setelah mendapat perlakuan siklus II. Dalam mengerjakan soal tes kedua ini, siswa lebih serius, tidak menoleh ke kanan dan kiri serta lebih cepat menyelesaikan soalsoal, 3) Nilai hasil tes Siklus II Berdasar hasil penelitian diketahui siswa yang telah mencapai KKM berjumlah 14 siswa atau sekitar 53,9\%. 
Siklus II diawali dengan momen refleksi siklus I, siklus II berdampak pada diri siswa yaitu dengan adanya peningkatan nilai tes. Peningkatan siswa yang mencapai KKM dibandingkan siklus 1 adalah sekitar $19, \%$. Hal tersebut dikarenakan semakin antusiasnya siswa dalam mengikuti pelajaran.

\section{d. Refleksi}

Pengamatan yang dilakukan pada siklus II yaitu partisipasi siswa terhadap kelompok menunjukkan bahwa partisipasi siswa dalam kelompok sudah bagus, meskipun masih ada satu orang siswa yang kurang dalam partisipasi kelompok.

\section{Paparan Siklus III}

a. Perencanaan

1) Guru menyiapkan materi pelajaran.

2) Guru mengatur siswa untuk dapat mengikuti pelajaran dengan baik.

3) Guru mempersipkan alat peraga berupa media Puzzle.

b. Pelaksanaan

1) Siswa berkelompok menurut kelompoknya masing-masing.

2) Siswa diajak menyanyi, bermain dan menari untuk menimbuhkan minat belajar.

3) Siswa menyebutkan jenis-jenis pekerjaan dan hasil dari pekerjaan tersebut.

4) Siswa bersama guru menyebutkan jenis-jenis pekerjaan dan memilih kepingan-kepingan Puzzle yang sesuai dengan jenis pekerjaan yang disebutkan guru.

5) Siswa bersama guru mendemonstrasikan penyusunan puzzle yang lebih rumit.

6) Siswa diajak mengulang materi secara bergilir bila kurang lengkap guru melengkapi.

7) Anak diberi pujian bila bisa menjawab pertanyaan, serta anak diberi sanksi bila anak tidak bisa menjawab pertanyaan dengan menyanyi dan baca puisi di depan kelas.

\section{c. Pengamatan}

1) Pengamatan dilakukan dengan melihat partisipasi siswa dalam kelompok. Hampir 90\% siswa telah aktif menjawab pertanyaan dari guru serta mengemukakan pendapat mereka, 2) Pengerjaan soal-soal sklus III Siswa secara antusias mengerjakan soal-soal yang ditugsakan setelah mendapat perlakuan siklus II, dalam mengerjakan soal siswa lebih serius dan tampak berlomba dalam menyelesaikan soalsoal, 3) Nilai hasil tes siklus III Berdasar hasil tes siklus III diketahui sejumlah 21 orang siswa atau sekitar 80,8\% siswa telah mencapai KKM..

Siklus III yang diawali dengan momen refleksi siklus II berpengaruh pada hasil belajar siswa. Refleksi dari proses pembelajaran pada siklus I, siklus II sangat berpengaruh terhadap siklus III dalam peningkatan nilai siswa. Peningkatan hasil belajar siswa pada siklus III dibandingkan siklus II sekitar 26,9\%. Selain itu diberlakukannya pembelajaran metode Puzzle ini juga menumbuhkan motivasi siswa dalam mengikuti pelajaran yang ditunjukkan dari tingginya konsentrasi siswa dalam mengikuti pelajaran, tidak ada siswa yang berbicara sendiri ataupun bermain sendiri.

\section{Paparan Peningkatan Hasil Belajar}

Hasil penelitian pada siklus 1 mengalami peningkatan, sebelumnya pada data awal menunjukkan dari 26 orang siswa hanya 6 orang siswa atau $23,1 \%$ yang dinyatakan tuntas (memenuhi kriteria KKM), dan 20 orang siswa atau $76,9 \%$ yang dinyatakan belum tuntas (belum memenuhi kriteria KKM). Pada siklus 1 diketahui 9 orang siswa atau $34,6 \% \%$ dinyatakan tuntas, dan 17 orang siswa atau $65,4 \%$ dinyatakan belum tuntas. Meskipun pada siklus ini terjadi peningkatan dalam hasil belajar, tetapi peningkatannya masih belum optimal. Sehingga kinerja guru masih perlu ditingkatkan, guru harus terus memotivasi siswa serta aktif melakukan diskusi, dan guru harus membimbing siswa tidak hanya secara klasikal tetapi perlu juga dilakukan secara individu. Selanjutnya peneliti melanjutkan ke siklus berikutnya yaitu siklus 2. Hasil pembelajaran pada siklus 2 dapat dicermati dengan baik. Tingkat pemahaman siswa terhadap materi pembelajaran yang diperlihatkan melalui penilaian proses dalam belajar dan hasil belajar dan hasil penilaian di akhir pelajaran terlihat lebih meningkat daripada hasil pada siklus 1. Hasil belajar pada siklus 2 mengalami peningkatan, yaitu 14 orang atau $53,9 \%$ telah dinyatakan tuntas sesuai dengan KKM dan 12 orang atau 46,1\% dinyatakan belum tuntas, karena belum memenuhi KKM. Dikarenakan pada siklus 2 belum mencapai kriteria yang diharapkan maka penelitian dilanjutkan pada siklus 3 . Hasil belajar pada siklus 3 menunjukkan peningkatan yang signifikan, diperoleh data 
bahwa 21 orang siswa atau $80,8 \%$ dinyatakan telah tuntas dan hanya 5 orang siswa atau $19,2 \%$ yang dinyakatan belum tuntas. Sebagaimana sesuai dengan KKM yang telah ditetapkan di awal adalah 70, maka pada siklus 3 ini penelitian di hentikan.

Data pembelajaran dari data awal sampai siklus 3 dapat dilihat pada tabel berikut ini.
Tabel Peningkatan Hasil Belajar Siswa

\begin{tabular}{|c|c|c|c|c|c|}
\hline No. & $\begin{array}{c}\text { Ket- } \\
\text { eran- } \\
\text { gan }\end{array}$ & $\begin{array}{c}\text { Data } \\
\text { Awal }\end{array}$ & $\begin{array}{c}\text { Siklus } \\
1\end{array}$ & $\begin{array}{c}\text { Siklus } \\
2\end{array}$ & $\begin{array}{c}\text { Siklus } \\
3\end{array}$ \\
\hline 1 & Tuntas & $\begin{array}{c}6 \\
\text { orang }\end{array}$ & $\begin{array}{c}9 \\
\text { orang }\end{array}$ & $\begin{array}{c}14 \\
\text { orang }\end{array}$ & $\begin{array}{c}21 \\
\text { orang }\end{array}$ \\
\hline 2 & $\begin{array}{l}\text { Belum } \\
\text { Tuntas }\end{array}$ & $\begin{array}{c}20 \\
\text { orang }\end{array}$ & $\begin{array}{c}17 \\
\text { orang }\end{array}$ & $\begin{array}{c}12 \\
\text { orang }\end{array}$ & $\begin{array}{c}5 \\
\text { orang }\end{array}$ \\
\hline
\end{tabular}

Adapun grafik peningkatan hasil belajar siswa dapat dilihat sebagai berikut.

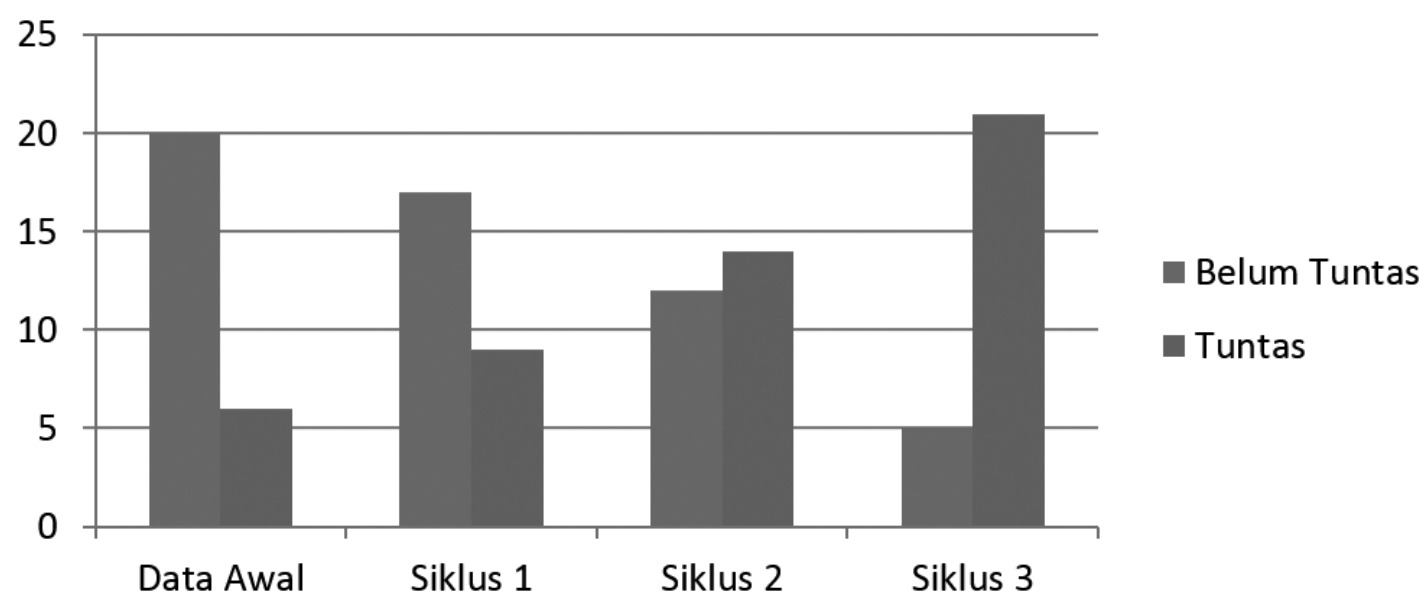

Berdasarkan grafik tersebut dapat diketahui bahwa dari data awal sampai siklus 3 hasil belajar siswa meningkat sekitar 57,7 $\%$. Adanya peningkatan hasil belajar yang terjadi pada setiap siklusnya, maka hal tersebut menunjukkan bahwa penelitian yang telah dilaksanakan berhasil dengan baik. Media Puzzle telah mampu meningkatkan hasil belajar siswa, karena siswa lebih bisa berkonsentrasi dan memperhatikan pelajaran, siswa dapat bekerjasama dengan kelompknya, serta siswa dapat memahami pelajaran dengan baik. Sehimgga hasil belajar yang diperoleh lebih meningkat. $\mathrm{Hal}$ ini diperkuat dengan dengan pendapat Rosdijati (2012: 40) bahwa dalam melakukan pembelajaran menggunakan media puzzle mempunyai kelebihan yaitu 1) melatih psikomotorik, 2) melatih daya ingat siswa, 3) suasana kelas tercipta dengan gairah, 4) di kelas terjadi interaksi antara siswa dengan siswa, dan antara siswa dengan guru, 5) siswa termotivasi untuk melakukan kegiatan, dan 6) siswa mampu bekerja sama dalam kelompoknya.

Dengan demikian dapat dibuktikan bahwa penerapan media puzzle dapat meningkatkan hasil belajar IPS pada materi jenis-jenis pekerjaan yang menghasilkan barang dan jasa di kelas III SDN 2 Paseh Kecamatan Paseh Kabupaten Sumedang Tahun Ajaran 2016/2017.

\section{Kesimpulan}

Berdasarkan analisis hasil penelitian diperoleh simpulan bahwa penggunaan media puzzle dalam pembelajaran IPS pada materi jenis-jenis pekerjaan yang menghasilkan barang dan jasa di kelas III SDN 2 Paseh Kecamatam Paseh Kabupaten Sumedang dapat meningkatkan hasil belajar siswa. Adapun hasil persentasi ketuntasan sebelum digunakan media puzzle hanya mencapai $23,1 \%$ siswa. Kemudian pada siklus III persentasi ketuntasan mencapai 80,8\%, sehingga meningkat sekitar 57,7\%. Hal ini menunjukkan bahwa media puzzle dinyatakan efektif dalam meningkatkan kemampuan belajar siswa.

Adapun saran bagi guru adalah guru hendaknya menggunakan media pembelajaran yang variatif, karena penggunaan media yang bervariatif akan membantu siswa untuk lebih mudah memahami materi pelajaran, salah satunya menerapkan media puzzle. Media puzzle dapat menciptakan siswa senang dan 
nyaman dalam belajar. Selain itu diharapkan guru dapat mengembangkan media puzzle dalam materi pelajaran lain. Saran bagi siswa adalah diharapkan siswa lebih konsentrasi dan tekun dalam belajar sehingga siswa dapat lebih mudah memahami materi yang diajarkan. Saran bagi peneliti lain, diharapkan peneliti selanjutnya dapat menjadikan hasil penelitian ini sebagai referensi bagi penelitian yang sejenis.

\section{Daftar Pustaka}

Aqib, Zaenal. (2015). Model-model, Media, dan Strategi Pembelajaran. Kontekstual (Inovatif). Bandung: Yrama Widya. .

Arikunto, Suharsimi. (2012). Penelitian Tindakan Kelas. Jakarta: Bumi Aksara.

Arikuto, Suharsimi. (2012). Dasar-dasar Evaluasi Pendidikan. Jakarta Bumi Aksara

Chairani, Fajriati. 2017. Efektivitas Media Pembelajaran Peta Buta Berbasis Puzzle Multimedia Ditinjau dari Hasil Belajar Siswa Kelas VI SD Negeri Sonosewu Bantul Yogyakarta Tahun Ajaran 2016-2017. Yogyakarta : Jurnal PGSD Indonesia. Vol.2, No. 3: 1-55.

Hamalik, Oemar. (2007). Proses Belajar Mengajar. Jakarta: Bumi Aksara.

Hamzah (2009). Model Pembelajaran, Menciptakan Proses Belajar yang Kreatif dan Efektif. Jakarta: Bumi Aksara
Hemawan, dkk. (2007). Proses Belajar mengajar. Bandung: FIP UPI.

Ischak. (2007). Pendidikan IPS di SD. Jakarta: Universitas Terbuka.

Khomsoh, Rosiana. 2017. Penggunaan Media Puzzle untuk Meningkatkan Hasil Belajar Siswa dalam Pembelajaran IImu Pengetahuan Sosial di Sekolah Dasar. Surabaya :Jurnalmahasiswa.unesa.ac.id/ article/5325/18.

Rosdijati, Nani. (2012). Panduan Pakem IPS $S D$. Jakarta: Erlangga.

Sapriya. (2007). Pendidikan IPS Konsep dan Pembelajaran. Bandung: PT. Rosdakarya.

Sudjana \& Ibrahim. (2014). Penelitian dan Penilaian Pendidikan. Bandung: Sindar Baru Algesindo Offset Bandung.

Sudjana \& Rivai. (2015). Media Pengajaran. Bandung: Sinar Baru Algensindo Offset Bandung.

Sugiyanto. (2015). Model-model Pembelajaran Inovatif. Jakarta: Yuma Pustaka.

Suprijono. (2009). Cooperative Learning Teori \& Aplikasi PAIKEM. Yogyakarta: Pustaka Pelajar

Widiyanti, Desi. (2007). Penggunaan Media Puzzle Piramida untuk Meningkatkan Prestasi Belajar. \{online\}. Tersedia: http://download . portalgaruda.org/article. 